\title{
Mosquito fauna (Diptera: Culicidae) of five different towns in Poland with special reference to the occurrence of human disease vectors
}

\author{
Elżbieta WEGNER
}

Museum and Institute of Zoology PAS, Wilcza 64, 00-679 Warsaw, Poland;

e-mail: wegner@miz.waw.pl

\begin{abstract}
The mosquito fauna has been studied in five Polish towns: Szczecin (31 species recorded), Świnoujście (23), Gdańsk (26), Warsaw (36) and Wroclaw (18). In all five towns 38 mosquito species have been recorded. Thirteen species were present in each of the study towns - Anopheles maculipennis s.1., Aedes cinereus, Ae. vexans, Culex pipiens, Culiseta anmulata, Ochlerotatus annulipes, Oc. cantans, Oc. caspius, Oc. cataphylla, Oc. communis, Oc. dorsalis, Oc. flavescens and Oc. leucomelas. Eight species were recorded in four towns: Anopheles claviger, Coquillettidia richiardit, Culiseta morsitans, Culex torrentium, Ochlerotatus excrucians, Oc. geniculatus, Oc. punctor and Oc. sticticus. The results are coincident with observations from several other European towns of Russia, Czech Republic and Hungary. Species typical of Polish towns occur commonly in comparative European towns. All of the competent mosquito vectors of human diseases known in Poland were registered in urban fauna (34.2\% species recorded) - most of them occurred numerously. It must be a factor, which increases the epidemiological hazard of mosquito-borne diseases in towns.
\end{abstract}

Key words: mosquito, Culicidae, Poland, human disease vectors, urban fauna

\section{INTRODUCTION}

The development of urban entomology and pest management is closely related to the growth of urban centres and the hazards of the introduction of exotic pests as well as human pathogens. World urbanization grows at an alarming rate, an estimated $56.5 \%$ of the world population will be living in urban centres by 2010 , the fastest growth occurring in developing countries (Robinson, 1996). In Europe the process is more advanced. Polish urban population grew from $31.8 \%$ in 1946 to $61.8 \%$ in 2002 . The growth regards primarily great and medium Polish towns. In Western Europe the urbanization is even more distinct, since it started earlier. By 1900 the urban population of Germany had reached $56 \%$ and France $41 \%$. According to the prognoses, in 2010 greater than $80 \%$ of the residents of these countries will live in urban areas (Robinson, 1996). In Great Britain 89\% of the population already lived in towns in 2005 (GB info). Thus there is a real need to learn more about mosquito species, which can develop in differrent urban biotopes, and especially those, which are vectors of human diseases. This will assume greater importance as global warming raises the epidemic hazard of emerging and re-emerging diseases - such as malaria, dengue, West Nile fever and Chikungunya (Ramsdale \& Snow 2000; Reiter 2001). During the last decade several outbreaks of mosquito-borne diseases in European and American towns were observed (Hubalek \& Halouzka 2000; CDC, 2007). It has been discovered that the epidemiological hazard is higher in towns than in rural areas. Smith et al. (2004) pointed out that the reason is the presence of a great number of people i.e. crowding of the mosquito vector's hosts. But the prerequisite for transmission of a pathogen is a presence of efficient vector species. 
The aim of the study was to show the prevalence of vector species in the urban mosquito fauna as well as the species richness of the fauna in general.

In Poland 49 mosquito species have been recorded so far. Thirteen of them are known to be competent vectors of human diseases, namely: Anopheles maculipennis s.1 (An. meseae and An. atroparvus) and An. claviger (malaria parasite), as well as Aedes cinereus, Ae. vexans, Coquillettidia richiardii, Culex pipiens, Cx. modestus, Culiseta annulata, Ochlerotatus cantans, Oc. caspius, Oc. dorsalis, Oc. sticticus (arboviruses - Tahyna, Sindbis, West Nile, etc). These are species common in Europe, and most of them tend to occur in mass numbers. Mosquitoes cause serious problems in many towns situated in the seaside regions or in the lowland river valleys.

\section{MATERIAL AND METHODS}

The mosquito fauna has been examined by different studies in five Polish towns: Szczecin, Świnoujście, Gdańsk, Warsaw and Wroclaw. Świnoujście and Gdańsk are seaside towns. Świnoujście occurs right at the open sea and Gdańsk at the Gdańsk Bay. Szczecin lays at the lower Oder River close to its mouth into Szczecin Bay (Oder estuary). Warsaw and Wroclaw lie inland in the lowland areas upon the greatest Polish rivers - Vistula and Oder, respectively (see Fig. 1).

The mosquito fauna of Szczecin was studied in 1949 and again in 1976-1977 (Lachmajer, 1949; 1954; Skierska et al., 1982) whilst the mosquitoes of Świnoujście - three times - the first time by Lachmajer $(1949,1954)$, then Łukasiak (1967) studied an outbreak of mosquitoes in August 1965. Last studies were carried out in Świnoujście port area in 1978 and 1979 (Burkiewicz \& Grablis, 1981). There is also a record from Świnoujście given by Peus (1929) who studied Culicidae of the region in 1920-s.

The mosquitoes of Gdańsk were studied several times from 1910s up to the present (Martini, 1920; Skierska \& Lachmajer, 1960; Kubica-Biernat et al., 2007). The mosquito fauna of Warsaw has been examined as often and thoroughly as that of Gdańsk. At first only malaria mosquitoes were studied (Tarwid 1938). In the 1950s and 1960s Lukasiak $(1956,1965)$ examined the whole mosquito fauna of Warsaw very thoroughly then in the 1970s Wegner (1982) studied Culicidae fauna in different habitats typical of urban areas. In the period 2001-2005 a study was carried out at Wilanów - the southern district of Warsaw (Wegner, unpubl.). Material is still occasionally collected.

The material collected in all of the towns mentioned above comprises both larval stages and adult mosquitoes captured in different natural habitats as well stables, sheds, cellars etc. Also specific studies concerning sibling species of Anopheles maculipennis group were carried out and the data of the occurrence of $A n$. messeae and An. atroparvus are available for these four towns. Another situation can be observed in Wroclaw. The study of mosquitoes of Wroclaw (1998-2000) started after the flood in 1997 and it has been carried out along with the monitoring of larval breeding sites (Rydzanicz \& Lonc, 2003). It focused on the problem of species which cause nuisance, and was supplemented by the author's occasional search for adult mosquitoes conducted during several visits to Wroclaw (Wegner, 2007). There is no material from stables and sheds (except for only one cellar) as well as no data regarding species of the Anopheles maculipennis group.

The town seems to provide differentiated and very favourable conditions for mosquitoes since Wroclaw lies upon five rivers, which tend to overflow every year, and the area is rich in seminatural wet habitats. In addition the climate is very mild in the region of Lower Silesia, of which Wroclaw is the capital.

The analysis has been made on the basis of data from the aforementioned literature. 


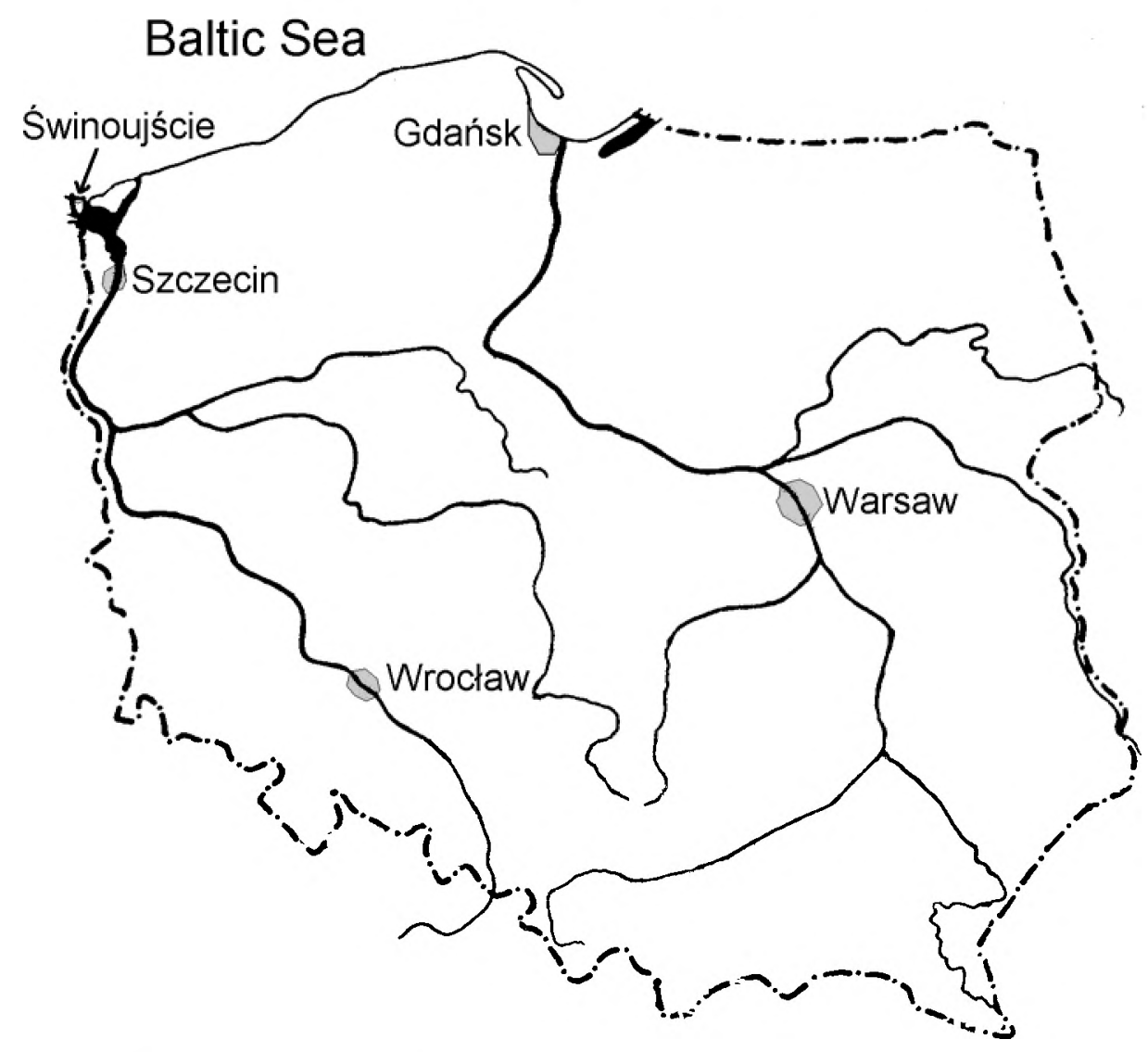

Fig. 1. Map of Poland. The distribution of the five study towns.

\section{RESULTS}

In the five study towns 38 mosquito species have been recorded: in Szczecin - 31 species, in Świnoujście - 23 species, in Gdańsk - 26 species, in Warsaw - 36 species and in Wroclaw 18 species (Table 1). There are three species, which cannot be distinguished from other similar species on the basis of characters of larva or adult females and therefore in routine faunal studies they had not been registered separately from other species of the group: i.e. Anopheles messeae and An. atroparvus were most often considered as An. maculipennis s.1. and Aedes rossicus was considered together with Ae. cinereus. Thus for some sites there is a lack of data marked in the table with question mark.

Thirteen species were recorded in all five study towns - the malaria mosquito Anopheles maculipennis s.1., both synanthropic species known in Poland (Culex pipiens and Culiseta annulata), three common temperate region snow-melt species (Ochlerotatus communis, Oc. cataphylla and Oc. leucomelas), two flood-water species (Aedes vexans and Ae. cinereus), as well as Oc. cantans, Oc. annulipes and Oc. flavescens. Also termophilous Oc. caspius and Oc. dorsalis have been recorded in all of the towns. Eight species have been recorded in four towns. Only three of them have not been recorded in Swinoujście - Coquillettidia richiardii, Ochlerotatus 
Table I. Check list of mosquito species recorded in five Polish towns: Szczecin, Świnoujście, Gdańsk, Warsaw and Wroclaw. Vector species bold and underlined. The members of the Maculipennis group can be distinguished from other species of the group exclusively on a basis of the characteristics of eggs and therefore often were recorded as a complex of species: i.e. Anopheles messeae and An. atroparvus are considered as An. maculipennis s.1. In Wroclaw eggs of anophelines have never been examined and there is a lack of data. Aedes rossicus was often recorded as Ae. cinerens. Thus for some sites there is a lack of data - in the table marked with question mark.

\begin{tabular}{|c|c|c|c|c|c|c|}
\hline No & Species & 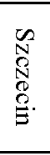 & 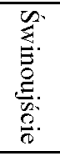 & 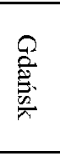 & 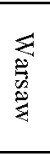 & 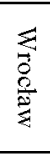 \\
\hline 1. & Aedes (Aedes) cinereus Meigen. 1818 & * & * & * & $*$ & $*$ \\
\hline 2. & Aedes (Aedes) rossicus Dolbeskin, Gorickaja \& Mitrofanova, 1930 & * & $?$ & $?$ & $*$ & $?$ \\
\hline 3. & Ae. (Adimorphus) vexans (Meigen. 1830) & $*$ & $*$ & $*$ & $*$ & $*$ \\
\hline 4. & Ochlerotatus (Finlaya) geniculatus (Olivier, 1791) & * & & * & * & $*$ \\
\hline 5. & Oc. (Ochlerotatus) annulipes (Meigen, 1830) & $*$ & $*$ & $*$ & * & $*$ \\
\hline 6. & Oc. (Och.) cantans (Meigen, 1818) & * & * & * & * & $*$ \\
\hline 7. & Oc. (Och.) caspius (Pallas, 1771) & * & * & * & * & $*$ \\
\hline 8. & Oc. (Och.) cataphylla (Dyar, 1916) & * & * & * & * & * \\
\hline 9. & Oc. (Och.) communis (De Geer, 1776) & * & * & $*$ & * & $*$ \\
\hline 10. & Oc. (Och.) cyprius (Ludlow, 1920) & * & * & & * & \\
\hline 11. & Oc. (Och.) detritus (Halliday 1833) & * & & & & \\
\hline 12. & Oc. (Och.) diantaeus (Howard, Dyar \& Knab, 1912) & * & & * & * & \\
\hline 13. & Oc. (Och.) dorsalis (Meigen. 1830) & * & * & $*$ & * & $*$ \\
\hline 14. & Oc. (Och.) enedes (Howard, Dyar \& Knab, 1913) & & & & * & \\
\hline 15. & Oc. (Och.) excrucians (Walker, 1856) & $*$ & * & & * & $*$ \\
\hline 16. & Oc. (Och.) flavescens (M ler, 1764) & * & * & $*$ & * & $*$ \\
\hline 17. & Oc. (Och.) intrudens (Dyar, 1919) & $*$ & $*$ & & * & \\
\hline 18. & Oc. (Och.) leucomelas (Meigen, 1804) & $*$ & $*$ & $*$ & $*$ & $*$ \\
\hline 19. & Oc. (Och.) nigrinus (Eckstein, 1918) & $*$ & & $*$ & $*$ & \\
\hline 20. & Oc. (Och.) punctor (Kirby, 1837) & $*$ & $*$ & $*$ & $*$ & \\
\hline 21. & Oc. (Och.) riparius (Dyar \& Knab, 1907) & $*$ & & $*$ & $*$ & \\
\hline 22. & Oc. (Och.) sticticus (Meigen, 1838) & $*$ & & $*$ & * & $*$ \\
\hline 23. & Oc. (Rusticoidus) rusticus (Rossi, 1790) & & & & $*$ & \\
\hline 24. & Anopheles (Anopheles) claviger (Meigen, 1804) & $*$ & $*$ & $*$ & * & \\
\hline 25. & An. (Ano.) maculipennis s.1. Meigen, 1818 & $*$ & $*$ & $*$ & $*$ & $*$ \\
\hline 26. & An. (Ano.) atroparvus van Thiel, 1927 & $*$ & * & $*$ & & $?$ \\
\hline 27. & An. (Ano.) messeae Falleroni, 1926 & * & * & * & * & $?$ \\
\hline 28. & An.(Ano.) plumbeus Stephens, 1828 & & & & * & \\
\hline 29. & Coquillettidia (Coquillettidia) richiardii (Ficalbi, 1889) & * & & * & $*$ & $*$ \\
\hline 30. & Culex (Barraudius) modestus Ficalbi, 1890 & & & & * & \\
\hline 31. & Cx. (Culex) pipiens pipiens Linnaeus, 1758 & * & $*$ & $*$ & * & $*$ \\
\hline 32. & $C x$. (Culex) torrentium Martini, 1925 & * & * & * & * & \\
\hline 33. & Cx. (Neoculex) territans Walker, 1856 & * & & * & * & \\
\hline 34. & Culiseta (Culiseta) alaskaensis (Ludlow, 1906) & & * & & * & $*$ \\
\hline 35. & Cs. (Culiseta) annulata (Schrank, 1776) & * & * & * & $*$ & * \\
\hline 36. & Cs. (Culiseta) subochrea (Edwards, 1921) & & & & $*$ & \\
\hline 37. & Cs. (Culicella) morsitans (Theobald 1901) & $*$ & * & $*$ & $*$ & \\
\hline \multirow[t]{2}{*}{38.} & Cs. (Culicella) ochroptera (Peus, 1935) & & & & * & \\
\hline & Number of species & 31 & $\begin{array}{c}23 \\
(1 ?)\end{array}$ & $\begin{array}{c}26 \\
(1 ?)\end{array}$ & 36 & $\begin{array}{c}18 \\
(3 ?)\end{array}$ \\
\hline
\end{tabular}


geniculatus and Oc. sticticus. Four other species were not recorded in Wroclaw (Anopheles claviger, Ochlerotatus punctor, Culex torrentium and Culiseta morsitans) and one species in Gdańsk (Ochlerotatus excrucians). Seven species have been met in only one of the study towns: Oc. detritus in Szczecin and six species in Warsaw - Anopheles plumbeus, Ochlerotatus rusticus, Oc. euedes, Culex modestus, Culiseta ochroptera and Cs. subochrea (Table 1). Five of the species were collected last time in suburbs of Warsaw (Wegner, unpubl.), the sixth one was recorded almost fifty years ago by Łukasiak (1965), also in suburbs.

All of the species which can transmit human diseases recorded in Poland have been registered in study towns (they make $34.2 \%$ of all species registered in towns). An. maculipennis (An. meseae and $A n$. atroparvus) and An. claviger - are vectors of the malaria parasite, while Cx. modestus, Cx pipiens, Cs. annulata, Ae. vexans, Ae. cinereus, Oc. cantans, Oc. caspius, Oc. dorsalis, Oc. sticticus, and Cq. richiardii - of arboviruses. Eight of these species (21\% of all species registered in towns) occurred in all of the study towns, three species (Oc. sticticus, An. claviger and Cq. richiardii) - in four towns and Cx. modestus has been registered in Warsaw only.

\section{DISCUSSION AND CONCLUSIONS}

The seven species found only in one of the study towns: Oc. detritus in Szczecin and six species of Warsaw - An. plumbeus, Oc. euedes, Oc. rusticus, Cx. modestus, Cs. ochroptera and Cs. subochrea need commentary. The occurrence of Oc. detritus in Szczecin seems quite natural - the species needs brackish water for its larvae to develop, which is present in Szczecin's Bay (the water of Oder estuary is slighty brackish). Moreover it seems that Oc. detritus is at the edge of its range in western Poland since it had not been found east of the Oder estuary despite the fact that it has been specially looked for along the Baltic coast (Skierska, 1974). Most of the remaining species have not been recorded in the town earlier - the possible reason is: the first species needs tree-holes, but lately it has adapted to use artificial containers as breeding sites (Schaffner, 2003) and became more common in anthropogenic habitats. Ochlerotatus rusticus, Oc. enedes, Culex modestus and Culiseta ochroptera were lately recorded in suburbs, in the seminatural habitats of Warsaw. However, the presence of Cs. subochrea needs verification. The presence in Warsaw's fauna of Culex modestus - the bridge vector which is a competent transmitter of West Nile virus - may have important epidemic consequences.

Szczecin's fauna shows characteristics of both inland and seaside mosquito fauna. Expected additions to its faunal list especially in suburbs are: Anopheles plumbeus, Ochlerotatus rusticus, Oc. euedes, Culiseta alaskaensis and Culex modestus.

The list of mosquito species recorded in Gdańsk and Warsaw seems to be almost complete in these towns faunal studies have been periodically repeated for nearly 100 years. One could expect two or three more species there. In Gdańsk it could be Anopheles plumbeus, Ochlerotatus excrucians and Culex modestus. Warsaw's fauna seems to be complete, only Cs. ochroptera, which was recorded by Lukasiak (1965) only once almost fifty years ago, now could be extinct in those areas due to the transformation of the environment of the town under urban pressure. Thus, its presence in urban environment needs verification. In remaining towns the species has not been recorded. On the other hand, there are more and more seminatural areas covered with a programme of nature protection in Polish towns. Some of them are favourable for different mosquito species. They may enrich the urban fauna with the species typical of wetlands.

The faunal list of mosquito species of Świnoujście seems to be incomplete although the study in the town has been carried out three times. Future faunal study should show the occurrence at least of Coquillettidia richiardil, Culex modestus and Ochlerotatus detritus there (all of the species were recorded in Wolin and Uznam Islands where Swinoujście is situated 
(Skierska, 1974). Ochlerotatus sticticus in very small numbers occurs in the islands, but as a species found typical in great lowland river valleys, it would be unusual to find it in Świnoujście, unless a flood occurs. Another situation can be observed as regards the tree-hole mosquito Ochlerotatus geniculatus. The species has not been recorded either in Świnoujscie or in the region's islands. This phenomenon needs explanation since it seems that the region provides favourable habitat conditions for the species.

Wroclaw seems to be as rich in habitats favourable to mosquitoes as Szczecin, but its mosquito fauna at the moment seems the poorest one of the five studied. The team for the monitoring of larval stages in the pools of Wroclaw recorded only eight of the most common species: Anopheles maculipennis, Aedes vexans, Culex pipiens, Culiseta annulata, Ochlerotatus cantans, Oc. communis, Oc. excrucians and Oc. sticticus (Rydzanicz \& Lonc, 2003). The study of adult mosquitoes conducted during 5 visits in Wroclaw confirmed the presence of seven species of the eight known before and showed 10 more species (Wegner, 2007). Thus mosquito fauna of Wroclaw must be rich and differentiated and any future study of fauna should show at least 10 more mosquito species in the town.

In a bibliography there are several papers dealing with the urban mosquito fauna of European towns of Russia: Leningrad = Petersburg (Fedorov, 1983), Moscow (Gornostaev \& Danilov, 1999), Volgograd (Fyodorova et al., 2006); of Czech Republic - Prague (Ryba \& Rettich, 1999), and Szeged in Hungary (Szepesszentgyörgyi \& Rentsendorj, 2006). The number of species recorded there is comparable with Polish observations: i.e. 24 mosquito species in Moscow, 26 species in Petersburg, 21 species in Prague, 20 species in Volgograd and 17 species in Szeged. Most of the Polish typical urban species have been recorded in all of the study European towns: Aedes cinereus, Ae vexans, Anopheles maculipennis s.1., Culex pipiens, Culiseta annulata and Ochlerotatus flavescens or in most of them: An. claviger, Oc. cantans, Oc. dorsalis, Oc. excrucians, Oc. sticticus and Coquillettidia richiardii. Several species typical for a colder climate commonly occur in Polish towns as well as in Moscow, Petersburg and Prague: Oc. cataphylla, Oc. communis, Oc. punctor, Cs. morsitans and Cs. alaskaensis while termophilous Oc. caspius and Cx. modestus are numerous in Southern towns (Volgograd and Szeged). Thus, urban species typical of Northern and Southern Europe are found in the towns of Poland and at the same time most of them are competent vectors of human diseases.

During the last decade Wroclaw and Gdańsk were subjected to flooding - Wroclaw in 1997 and Gdańsk in 2001. In Gdańsk the mosquito fauna was studied just before flooding and it was observed that after the disaster the density of $C x$. pipiens grew greatly and its percentage rose from $23.8 \%$ (prior to 2001) reaching more than $97 \%$ of all mosquitoes occurring in the town (Kubica-Biernat et al. 2007). Moreover, the situation lasted for some time after the flood, although the percentage of $C x$. pipiens gradually decreased (76.5\% in 2002). Also in Wroclaw $C x$. pipiens heavily predominated in the urban habitats subjected to inudation in 1997 . The phenomenon could have epidemic consequences since the species is a competent vector of West Nile Virus and other arboviruses. It has been incriminated as the main WNV vector in the outbreaks of WNE in Romania (Bucarest), Russia (Volgograd) and America. In Poland WN fever is not distinguished, but epidemic statistics show 3-5 fold increase of the frequency of aseptic meningitis in the areas flooded in 1997 and 2001, which is correlated with plague occurrence of Cx pipiens (Wegner, 2004). Vector competence for West Nile virus of six more species typical of urban fauna (Aedes cinereus, Ae. vexans, Ochlerotatus cantans, Oc. caspius, Oc. dorsalis, Oc. sticticus, Coquillettidia richiardii) has also been proved.

There is a high percentage of competent vectors of human diseases in urban fauna $(34.2 \%$ of all species registered in towns) and most of them occur regularly as an element of the fauna. Also considering that they occur numerously must altogether certainly be an important factor 
affecting the circulation of human pathogens in urban environment, and must also increase the epidemiological hazard of mosquito-borne diseases in towns. The knowledge of the species composition of mosquito fauna would be very helpful in estimating this hazard in different urban agglommerations.

\section{REFERENCES}

BurkiEwicz A. \& GRABLIS E. 1981. A study of the mosquito populations in the Swinoujście Port area. Bulletin of the Institute of Maritine and Tropical Medicine 32: 269-276.

CDC 2007. Division of Vector Borne Infectious Diseases: Arboviral Encephalitis Cases Reported in Humans, United States, 1964-2006, available from: http://www.cdc.gov/ncidod/dvbid/arbor/arbocase.htm

FEDOROV W. G. 1983. Some materials on blood-feeding mosquitoes (Diptera: Culicidae) of Leningrad and its surroundings. Parazitol. Zbornik 31: 62-75. [in Russian]

Fyodorova M. V., Savage H. M., lopatina J. V., Bulgakova T. A., Ivanitsky A. V., Platonova O. V., Platonov, A. E. 2006. Evaluation of Potential West Nile Virus Vectors in Volgograd Region, Russia, 2003 (Diptera: Culicidae): Species Composition, Bloodmeal Host Utilization, and Virus Infection Rates of Mosquitoes. Journal of Medical Entomology 43: 552-563.

GORnOSTAEV R. M. \& DANILOV, A. V. 1999. Mosquitoes (Family Culicidae) of Moscow and Moscow Province Moscow: KMK Scientific Press, 342 pp. [in Russian]

Great Britain information: available from: http://www.studentsoftheworld.info/pageinfo_pays.php3?Pays=GBR\&Opt=population

HUBALEK Z. \& HALOUZKA J. 2000. West Nile Fever - a Reemerging Mosquito-Borne Viral Disease in Europe. Emerging Infectious Diseases. 5: 643-650.

Kubica-Biernat B., Kowalska-Ulczyńska B. \& Stańczak J. 2007. Mosquito fauna (Diptera: Culicidae) of the Gdansk Agglomeration. In: BUCZEK A. \& BŁASZAK Cz. (eds) Arthropods Environment, pathogens and hosts. Lublin: 61-66. [in Polish, English abstr.]

LACHMAJER J. 1949. Badania nad ekologią komarów rodzaju Anopheles. Przegl. Epidem., 3: 1-16. [in Polish]

LACHMAJER J. 1954. On mosquito fauna of Szczecin. Acta Parasitologica Polonica 2: 39-51. [in Polish]

LUKASIAK J. 1956. Ecology and biology of adult Anopheles maculipennis Meig., 1818 in the area of Warsaw. Acta Parasitologica Polonica 4: 561-581. [in Polish]

LUKASIAK J. 1965. The studies of the occurrence of Culicinae (Diptera, Culicidae) in Warszawa and its surroundings. Fragmenta Faunistica 12: 1-13.

LUKASTAK J. 1967. Mass occurrence of Culicidae in Świnoujście in August 1965. Wiadomości Parazytologiczne 13: 113-115. [in Polish]

MARTINI E. 1920. Uber Stechmucken besonders deren europaischen Arten und ihre Bekampfung. Arch. Schiff. u. Tropenhyg. 24: 1-259.

PEUS F. 1929. Beitrage zur Faunistik und Okologie der einheimischen Culiciden. Zeitschrift für Desinfektion, 3: 1-12. Dresden.

RAMSDALE C.\& SNOW K. 2000. The tiger mosquito - potential settler or already here? Environmental Health Journal. November 2000.

REITER P. 2001. Climate change and mosquito-borne disease. Health Perspect. March; 109 (Suppl. 1): $141-161$.

ROBINSON W. H. 1996. Urban Entomology: Insect and mite pests in the human environment. Chapman \& Hall, New York. $430 \mathrm{pp}$.

RYBA J. \& RETTICH F. 1999. Mosquitoes (Diptera: Culicidae) of Prague. In: RoBINSON W. M, RetTICH F. \& RAMBO G. W. (eds) Proceedings of the $3^{\text {rd }}$ International Conference on Urban Pests. Prague. Czech Republic: 657.

RYDZANICZ K. \& LONC E. 2003. Species composition and seasonal dynamics of mosquito larvae in the Wroclaw, Poland area. Journal of Vector Ecology: 255-266.

SKIERSKA B. \& LACHMAJER J. 1960. The fauna of Culicidae in the city of Gdańsk and its environs. Bulletin of the Institute of Maritine Medicine in Gdańsk 11: 157-163.

SKIERSKA B., SZADZIEWSKA M. \& GRABLIS E. 1982. Mosquitoes (Culicidae) of the port area and the town of Szczecin. Wiadomości Parazytologiczne 28: 69-72. [in Polish]

SKIERSKA B. 1974. Komary (Diptera, Culicidae) zachodniej części wyspy Wolina i poludniowo-zachodniej części Uznamu. Poznańskie Towarzystwo Przyjaciól Nauk, Wydział matematyczno-przyrodniczy, Prace Komisji Biologicznej, Warszawa-Poznań. 79 pp. [in Polish]

SCHAFFNER F. 2003. Mosquitoes in used tyres in Europe: species list and larval key. European Mosquito Bulletin: 16: 7-14.

Smith D. L., Dushoff J. \& MCKenZIE F. E. 2004. The Risk of a Mosquito-Borne Infection in a Heterogeneous Environment. PLoS Biol 2(11): e368 doi:10.1371/journal.pbio.0020368

SZEPESSZENTGYÖRGYT Á. \& RENTSENDORJ O. 2006. Seasonal changes in the mosquito fauna (Diptera, Culicidae) in the city of Szeged in 1999. Tiscia 35: 41-47. 
TARWID K. 1938. Notatki faunistyczne o muchówkach Polski. Fragm. Faun. Musei Zool. Pol. 3: 1-8. [in Polish] Wegner E. 1982. Mosquitoes (Diptera, Culicidae) of Warsaw and Mazovia. Memorabilia Zoologica 36: $201-216$.

WEGNER E. 2004. Estimation of a risk of West Nile fever outbreak in Poland. In: Buczek A., Blaszak Cz. (eds) Arthropods. Parasite - host interaction. Lublin: 265-272. [in Polish, English abstr.]

WEGNER E. 2007. Additions to the faunal list of mosquito (Diptera: Culicidae) species in Wroclaw, Poland. European Mosquito Bulletin 24: 1-3.

\section{STRESZCZENIE}

[Fauna komarów (Diptera: Culicidae) pięciu miast Polski ze szczególnym uwzględnieniem występowania w miastach gatunków będących wektorami chorób ludzi]

W pięciu miastach Polski zarejestrowano 38 gatunków komarów (Diptera: Culicidae): w Szczecinie - 31 gatunków, w Świnoujściu - 23, w Gdańsku - 26, w Warszawie - 36 i we Wroclawiu - 18 gatunków. We wszystkich pięciu miastach występuje $13 \mathrm{z}$ nich: Anopheles maculipennis s.1., Aedes vexans, Ae. cinereus, Culex pipiens, Culiseta annulata, Ochlerotatus communis, Oc. cataphylla, Oc. leucomelas, Oc. cantans, Oc. annulipes, Oc. flavescens, Oc. caspius i Oc. dorsalis. W 4 miastach stwierdzono: An. claviger, Coquillettidia richiardii, Oc. geniculatus, Oc. excrucians, Oc. sticticus, Oc. punctor, Cs. morsitans and Cx. torrentium. Wszystkie gatunki komarów będące skutecznymi wektorami chorób ludzi występujące w Polsce zanotowane byly w miastach (stanowily 34,2\% fauny miast, przy czym większość z nich występuje w dużych liczebnościach). Jest to z pewnością czynnik istotnie zwiększający ryzyko zachorowania na choroby transmisyjne przenoszone przez komary $w$ miastach $w$ porównaniu do terenów pozamiejskich. 